\title{
Studying and Evaluating Sustainable Materials for Converting Plastic Waste to Fuel
}

\author{
Ameen Abdelrahman ${ }^{1}$, Hassan A. Dosky ${ }^{2}$, Hamdy F. M. Mohamed ${ }^{3}$, Aly M. Radwan ${ }^{4}$ \& Asmaa S. Hamouda ${ }^{1}$ \\ ${ }^{1}$ Department of Renewable Energy Science \& Engineering, Faculty of Postgraduate Studies for Advanced Science \\ (PSAS), Beni-Suef University, Egypt. \\ ${ }^{2}$ Faculty of Science, Chemistry Department, Benha University, Benha, Egypt \\ ${ }^{3}$ Physics Department, Faculty of Science, Minia University, Egypt \\ ${ }^{4}$ National Research Center, Chemical Engineering \& Pilot Plant Department, Cairo, Egypt \\ Correspondence: Ameen Abdelrahman, Department of Renewable Energy Science \& Engineering, Faculty of \\ Postgraduate Studies for Advanced Science (PSAS), Beni-Suef University, P.O. Box 62511 Beni-Suef, Egypt. E- \\ mail: chem.shaha@hotmail.com
}

$\begin{array}{lr}\text { Received: May 6, } 2018 & \text { Accepted: May 16, } 2018 \quad \text { Online Published: May 31, } 2018 \\ \text { doi:10.5539/eer.v8n1p73 } & \text { URL: https://doi.org/10.5539/eer.v8n1p73 }\end{array}$

\begin{abstract}
Gasification is one of the most important solutions for plastic waste management. We researched the conversion of plastic waste to fuel using sustainable material (Nano Clay) modified with Nano transition metals $\left(\mathrm{TiO}_{2}, \mathrm{MnO}\right.$, and $\mathrm{ZnO}$ ). This was processed in a fix bed reactor design. After studying the reaction mechanism of the gasification process, we evaluated the optimize (reactor temperature, reaction time and feeding ratio of the modified catalyst) on the gasification process with its application for the modified catalyst on the degradation of polyethylene high density(PEHD), other waste plastic to fuel $\left(\mathrm{CH}_{4}, \mathrm{H}_{2}\right.$, and other light component gasses). This method can be used as an important resource for renewable energy (like generating electricity and clean fuel), rather than waste for landfills and the incineration process which is the main source of $\mathrm{CO}_{2}$ emissions.
\end{abstract}

Key words: modified catalyst, gas yield, polyethylene high density, waste plastic, gasification, $\mathrm{TiO}_{2}, \mathrm{MnO}, \mathrm{ZnO}$ and $\mathrm{CH}_{4}$

\section{Introduction}

Many plastic productions started in 1950 and this caused almost 8 billion metric tons of waste mainly in disposable material. Scientists are trying to find a better solution for this humongous waste for landfills and an alternative resource for fossil fuels to change to an environmentally friendly renewable fuel like biodiesel (Semwal, Arora, \&Tuli,2011). Plastic (polymeric) materials are known for their universal use and rapid growth in various markets. Given the low density, strength, ease of design, process ability, durability, low weight and low cost of plastic, it became very popular in different sectors such as packaging, automotive, industrial applications, piping, construction, thermal and acoustic insulation (Rebeiz, K. S., Craft,1995). The increase in manufacturing and use of polymeric materials are the causes of enormous plastic waste [Rafatet al (2008), \&Buclet, N, Brandt 2010). Plastic recycling is a method that can solve this problem compared to throwing the plastic waste in landfills or incineration. The specified benefits of gas over solid fuel and the gasification process is that they transfer the heating value of the solid fuel to a gaseous energy carrier (Van Swaaij, 1981).

For example, gases are easy to transport and clean. They efficiently combust with less excess air and they emit a lower level of some pollutants Comolli, et al (1997). Catalysis has become essential for the chemical industry. It makes use of natural resources while reducing the pollution during the chemical process. Also, catalysis has become a foundation of large-scale production in the chemical and petroleum industry (Yadav, Nair (1993), Vermeiren, et al (2009), Chen et al (2015) and Sharifzadeh, et al (2015). However, there are still problems that require constant solutions Wolczanski, Chirik, (2015) \& Tanaka (2010). With the development of nanotechnology, catalysis has introduced both advantages and disadvantages. For example, metal nanomaterial as a heterogeneous catalyst Dutta et al (2015) has very high catalyst activity and selectivity for specific reactions. Nano catalysts used for catalytic chemical reactions mainly contain the oxidation reaction, the reduction reaction Yasukawa et al, (2015), the coupling reaction Zhang, Shen (2015) \& Zhang, et al, (2015) and the electrochemical reaction (Zhou 
et al (2003), Tripkovic et al, (2002), Choi et al (2006), Shen et al (2015) and Xiao, et al (2015). Nano catalysts have been proven successful in many industries such as adsorbents, catalysts or catalyst supports, and ion exchangers. Clay-modified catalysts will be explored, according to different modification methods: such as thermal, acid and cation exchange, and pillared clays. In addition, the synthetic catalysts from clays zeolites and alumina were also explored.

The first hydrocracking process evolved over 8 decades ago. It was based on acid-modified clays Centi, G. \&, Perathoner, S. (2008) but zeolites and aluminosilicates were announced later. Clays are still used in some cases such as in treating some heavy fractions. Clays with different acidities can be acquired by thermal treatment before preparing the catalyst. The temperature of the thermal treatment of clay determines the type and concentration of the hydroxyl groups (Herrero et al, (1990) and this thereby determines its acidity. Montmorillonites or acidmodified montmorillonites have been used for numerous reactions (Mishra et al (2010), Turgutbasoglu et al, (2005) and Hettinger (1991) Transition metal-based catalysts, particularly supported Ni catalysts, have been greatly used for biomass gasification due to their high activity in tar cracking and improving the quality of the produced gas (Baker \&Mudge 1987).

The cracking of plastic polymerics into their component monomer or other low molecular weight hydrocarbons has become an essential process for getting rich light hydrocarbon and aromatic olefin components. Also, a large amount of plastic waste is expanded quickly every year (Worldwatch Institute, 2016). Pyrolysis and/or gasification of plastic waste such as PEHD and its waste serve as a pertinent tool for restoring energy and plastic waste disposal simultaneously Al-Salem et al. (2009). Compared with other proposition feedstock like biomass and coal, PEHD has a higher heating value and it is much cleaner in terms of fuel quality. This causes less fuel pre-processing costs. Pyrolysis or gasification of PEHD results in a product stream rich in hydrogen and minimal $\mathrm{CO}$ or $\mathrm{CO}_{2}$ content compared to cellulose-based wastes (biomass) (Vassilev et al., 2010\& (Liu et al., 2014a) that yield relatively higher carbon monoxide and lower hydrogen product compositions. This is mainly because of the presence of oxygen in the cellulose-based feedstock.

\section{Material and Methods}

\subsection{Materials}

\subsection{Polyethylene High Density (PEHD) Sample}

Feedstock used for the process was PEHD B1054, a high density polyethylene specially developed for large blow molding and jerry cans. The material offers high stiffness, good process ability and it is an excellent combination of stiffness/ESCR. Saudi Basic Industries Corporation, SABIC. All chemicals used for nano-oxide metals were purchased from Lobe chime (India) and they were used without purification. Also, the raw material plastic waste (PVC, PEHD, PELD, EP, STYRENE, resin) was collected from Beni suef university Camp.

\subsection{Catalyst}

The structure of montmorillonite is a 2-to-1 layered smectite clay mineral with a platy. Each layer has 2 tetrahedral sheets containing an octahedral sheet between individual platelets. The thicknesses are just one nanometer, but surface dimensions range between 300 to more than 600 nanometers. Hundreds or thousands of these layers were stacked together with Vander Waals forces to form clay particles (Murray,2007)

The modified catalyst used in our study is bentonite modified with three transition metal oxides $\left(\mathrm{TiO}_{2} / \mathrm{MnO}_{2} /, \mathrm{ZnO}\right)$ in Nano size. Catalysts were prepared in Nano scales by sol-gal and co-precipitation methods. Their characterizations are outlined in our previous work (Belova et al,(2008), V. Subramanian et al (2005), iyadh, (2015), M.Galamboš et al, (2010).

\subsection{Methods}

\subsubsection{Gasification System.}

The gasification of plastic polymer (PEHD) and other different plastic waste was carried out using a fixed-bed reactor (SS 318, $0.98 \mathrm{~mm}$ ID). The height of the reactor was $40 \mathrm{~cm}$ with a capacity volume of $40 \mathrm{~cm} 3$. It was heated by an electrical furnace. The reactor had three main parts that were connected together during preparation for the experiment. The feeding waste plastic and catalyst were added through the lower part, and the upper and lower part were joined together with a union fitting connection as shown in Fig-1. In a typical experiment of gasified $1 \mathrm{~g}$ of sample (with and without catalyst), then loaded together inside, adjustable other parameters (temperature at $750^{\circ} \mathrm{C}$ and reaction time is one hour) for the reactor process. This design is installed in the Faculty of Post Graduated for Advanced Science, Renewable energy Department, Beni suef University in Egypt (Aly M. Radwan, (2015) 


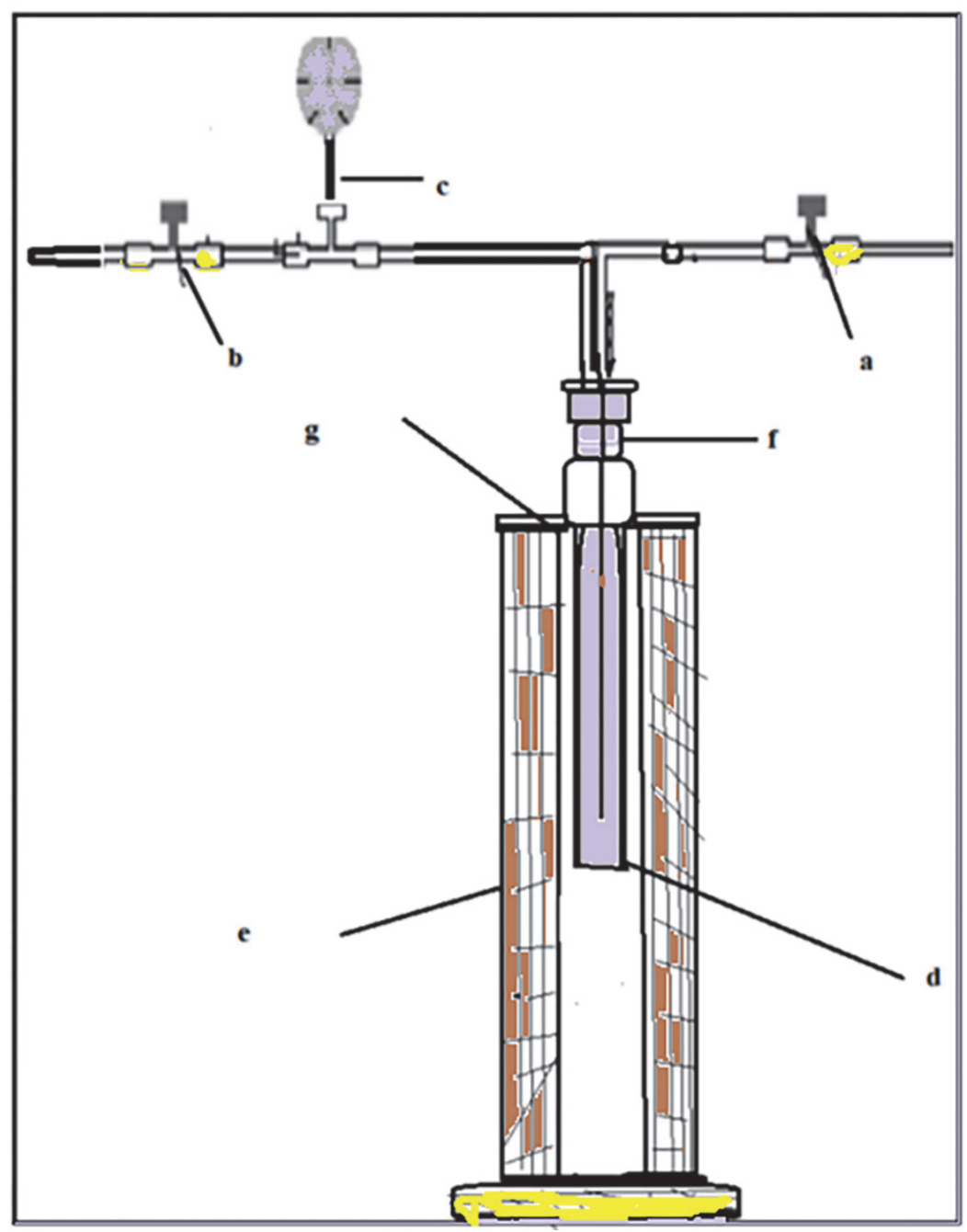

Figure (1). Schematic of the gasification system with (a) inlet valve, (b) outlet valve, (c) pressure gauge, (d) gasified reactor, (e) furnace, (f) union connection and (g) thermocouple k-type

\subsubsection{Gasification PROCEDURE}

The loaded reactor was placed inside the furnace at the selected reaction temperature and heated for the required 10 to 15 minutes to reach isothermal heating. The electrical furnace was $65 \mathrm{~cm}$ long, $8 \mathrm{~cm}$ ID and $22 \mathrm{~cm} \mathrm{OD.} \mathrm{It}$ was completely insulated with glass wool material and it was used to maintain the reaction temperature for the gasification of plastic waste. A controller for temperature with a thermocouple (type K) was connected to the outer surface of the reactor for recording and controlling the temperature of the reactor. within complete reaction, we removed the reactor from the furnace and it was cooled with an electrical fan. It took 15 minutes for the reactor to cool down to room temperature. Afterwards, we collected producer gases and injective inside GC for the gas yield analysis and other remaining solids (char) were also collected to conduct other tests.

\section{Results}

\subsection{Study of Reaction Mechanism of the Gasification Reaction.}

The reaction mechanism of the modified catalyst with clay and poly ethylene high density or other plastic is illustrated in fig 2. The chemical structure of bentonite clay is sodium montmorillonites which has the chemical composition $\mathrm{Na}_{0.2} \mathrm{Ca}_{0.1} \mathrm{~A}_{12} \mathrm{Si}_{4} \mathrm{O}_{10}(\mathrm{OH})_{2}\left(\mathrm{H}_{2} \mathrm{O}\right)_{10}$. Smectite minerals are composed of two silica tetrahedral sheets with a central octahedral sheet. They are designated as a 2:1-layer mineral. It is easily dissolved in water. Water molecules and cations occupy the space between the 2:1 layers by making coordination complexes (DeStefanis, 2006). 
Various modifications of clays such as thermal-, acid-, alter the structure properties and produce catalysts with high acidity, surface area, porosity and thermal stability (Ding Z et al, (2001), Williams (2006) \& Murray (1999).

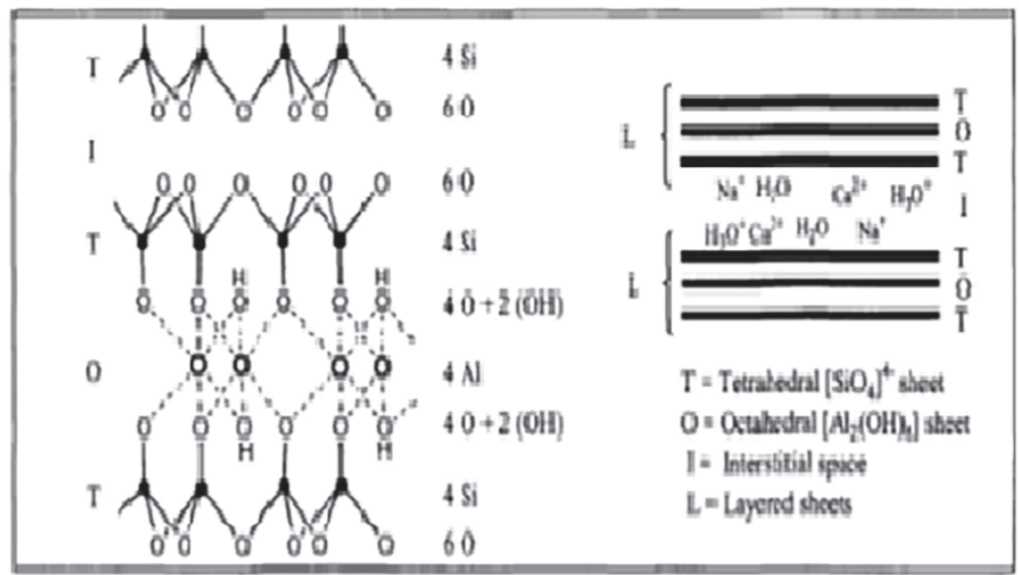

Figure (2). Structure of sodium montmorillonite

3.1.1 Metals of Transition Elements Have Different Oxidation States Which Make It Easy to Chelate with Some Sites of Clay Containing $\mathrm{OH}$ as a Ligand

The impregnation process explains how transition metals chelate with aluminum and silica elements such as vanadia, chromia, zirconia and alumina. Pillared clays are modified and the ions on the clays are exchanged with specific chemicals such as Al-hydroxide which goes into an interlayer position Gilman, Jeffery et al,(199. Particle size, surface area, and aspect ratio are highly important characteristics desired in Nano clays. The length and breadth of the particles can range from $1.5 \mathrm{~nm}$ to a few tenths of a micron. The third dimension of a particle has been described in literature as thickness, width, or diameter. However, diameter seems more appropriate. The diameter of a particle is exceptionally smaller relative to its length $(1 \mathrm{~nm})$.

Therefore, an extremely high average aspect ratio (length to diameter ratio) of 200 to 500 is possible. A small amount of Nano bentonite exhibits a high surface area; i.e., a Nano clay product is known with a surface area in excess of $750 \mathrm{~m}^{2} / \mathrm{g}$, (Clay Minerals-Sci-Tech (2007). The surface area for newer metals oxide $\mathrm{TiO}_{2}, \mathrm{MnO}$ and $\mathrm{ZnO}$ play an important role in catalyzing polymers (plastic) with a surface area of $287.1,253$ and $15.45 \mathrm{~m}^{2} / \mathrm{g}$ i.e $\mathrm{TiO}_{2}>\mathrm{MnO}>\mathrm{ZnO}$ of the same order for the ease of catalysis.

The Lewis acidity of the metal ions correlates with the charge -to-size $(\mathrm{z} / \mathrm{r})$ ratio. The higher $\mathrm{z} / \mathrm{r}$, the stronger the Lewis acidity of the cation. This results in more polarization power of the metal centre and more of a catalyst effect. The $\mathrm{z} / \mathrm{r}$ for Ti, Mn and $\mathrm{Zn}$ are 287.1,253 and $15.45 \mathrm{~m} 2 / \mathrm{g}$, respectively Kuo-Tseng et al (2012). However, despite a much higher $\mathrm{Z} / \mathrm{r}$ ratio for $\mathrm{Zr}^{4+}$ and $\mathrm{HF}^{4+}$ (5.56 and 5.63) respectively, the corresponding complex exhibited poor catalytic activity.

The second factor that has a great effect on the reaction mechanism is the electronic configuration for electrons in the d- orbital for transition element metals and the p-orbital Oxygen atom in side Bentonite sheets. 


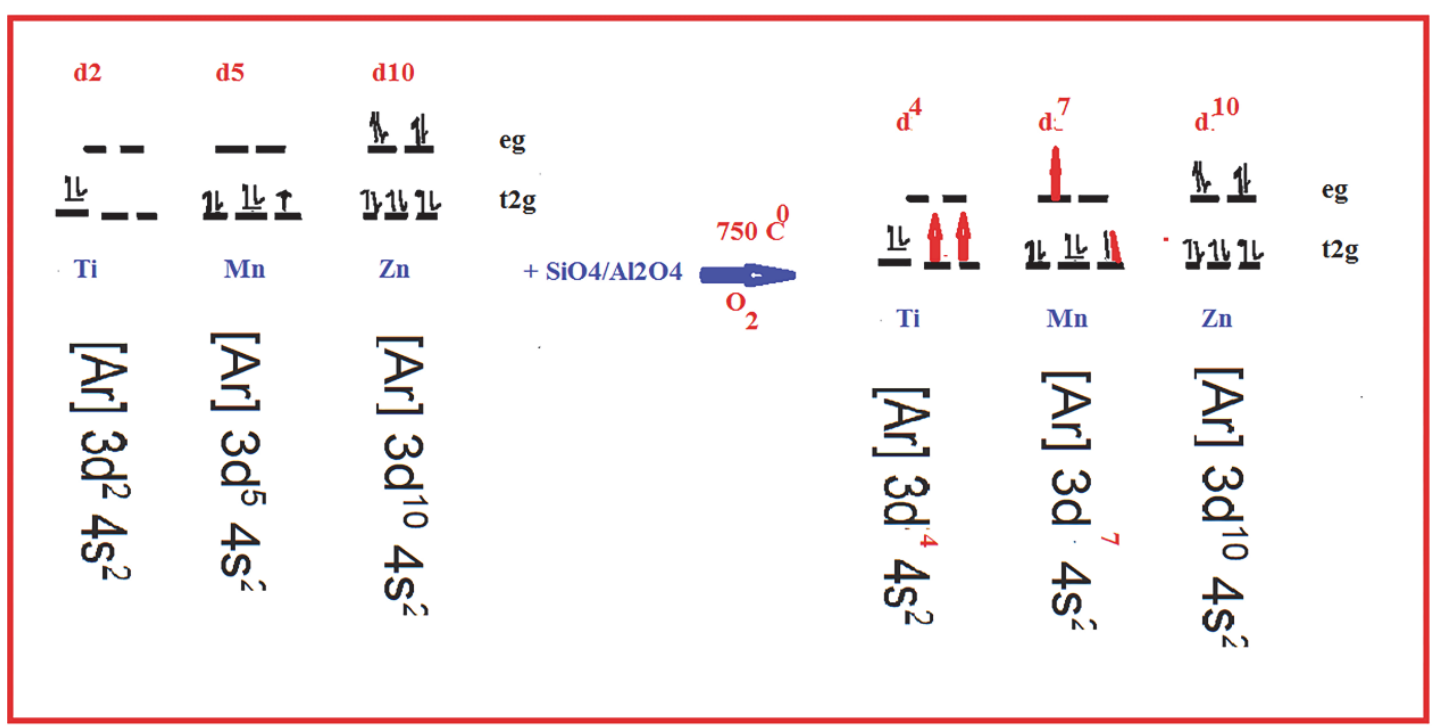

Figure (3). Schematic of reaction mechanism for the electronic distribution in the d-orbital of the outer shell

The electronic state for transition metals (Ti, Mn and $\mathrm{Zn}$ ) is illustrated by figure (3). According electronic configuration of three transition elements in $\mathbf{t 2} \mathbf{g}$ (lower energy state) and eg (excited state), in case titanium atom there are four empty orbitals in the $\mathrm{d}$ shell. So, it is easy to fill 2 of them with 4 electrons according to the hunds rule so it shearing or chelating with free electron of $\mathrm{O}$ atom. The charge transfer in which an electron is momentarily transferred from $\mathrm{O}$ in the $\mathrm{OH}$ group of $\mathrm{Bn}$ to the $3 \mathrm{~d}$-orbital of the metal (the momentarily changes $\mathrm{O}^{2-}$ to $\mathrm{O}^{-}$and reduces the oxidation stat of the metal Ti or $\mathrm{Mn}$ from $4^{+}$to $3^{+}$) can promote through the d-orbital of unequal energy that is freely in case of Ti to $\mathrm{Mn}$ and does not occur in the case of $\mathrm{Zn}$. On the other hand, this free transition affects the ease of catalization of the Nano composite through PEHD as seen in in fig -4. The structure of the clay particles is perceived in layers. Each layer is composed of two types of structural sheets: octahedral and tetrahedral. The tetrahedral sheet is composed of silicon-oxygen tetrahedra linked to neighboring tetrahedral sharing three corners. This results in a hexagonal network (Y. Rao \& Blanton (2008) .

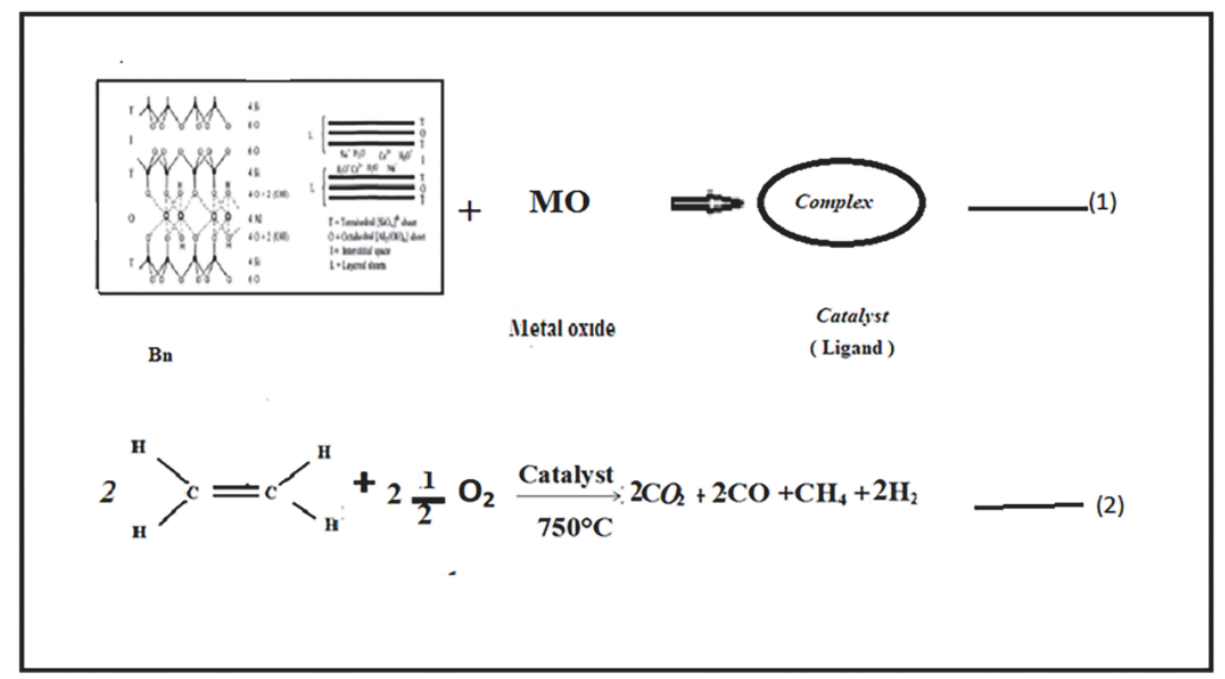

Figure (4). Schematic illustrating the complex formation

The remaining fourth corner of each tetrahedron forms a part of the adjacent octahedral sheet. The octahedral sheet is usually composed of aluminum or magnesium in six-fold coordination with oxygen from the tetrahedral sheet and the hydroxyl. The two sheets together form a layer, and several layers may be joined in a clay crystallite by interlayer cations, Vander Waals force, electrostatic force or hydrogen bonding. 


\subsection{Studying Optimized Parameters for Gasification Processes.}

\subsubsection{Studying Temperature with Reaction Time on the Gasification Process for PEHD.}

There are many parameters that affect the gasification process such as pressure, temperature and reactions times. They have a great impact on the quality and quantity of product distribution, and they affect the degradation of polymer (plastic). By increasing the temperature, the polymer is converted from plastic to a glassy state, rubbery state, liquid state, and a decomposed state. The reaction mechanism of polymerization passes four stages during the plastic degradation process: initiation, propagation, hydrogen transfer, and termination reactions. Through the initiation reaction process, there are three types of cracking or reforming processes: random, end chain, and chain strip cracking (Bockhorn et al., 1999; Faravelli et al., 1999, 2003; Kruse et al., 2001, 2002, 2003, 2005; Levine and Broadbelt, 2008, 2009; Marongiu et al., 2003, 2007; Poutsma, 2003, 2005, 2009; Westerhout et al., 1997a,b) They are determined by the side functional group on the plastic molecular carbon backbone. Then, there are propagation reactions, especially $\beta$-scission, (Vinu and Broadbelt, 2012b) which is the cracking of large molecular weight. The second factor which is also important for degrading plastic is reaction time. This means the economic value for the industrial sector. The reaction time is inversely proportional to the temperature and pressure. It gradually increases with increasing temperature and then it's constant. This means the polymers are completely converted. This is shown in fig -5 which illustrates the typical relation of temperature and pressure against the reaction time during the degradation of polyethylene high density (PEHD) in the gasification process. By increasing the temperature, the degradation of the polymer increases with increasing pressure until it is fixed at $750^{\circ} \mathrm{C}$. This is at almost one hour and there is no change in other premasters. This means there is complete conversion and the gasification process is done. The cracking of plastic polymer waste is a very complex process, which consists of many reactions and products. By increasing the temperature, we demonstrated the cracking of plastic. From our experiments, we reached optimal conditions for the gasification process of degrading poly ethylene high density to fuel at $750{ }^{\circ} \mathrm{C}$ and a one hour reaction time. We also got a high ratio of gases with reduced liquid which contaminated with tar. This has a negative impact and plugs the pipe and precipitate on the inner surface of the reactor. in addition to char (solid waste is easy recycle or reused management) the results from the gasification of plastic can be used in other industrial fields rather than emission carbon di oxide which result direct combustible or incineration process.

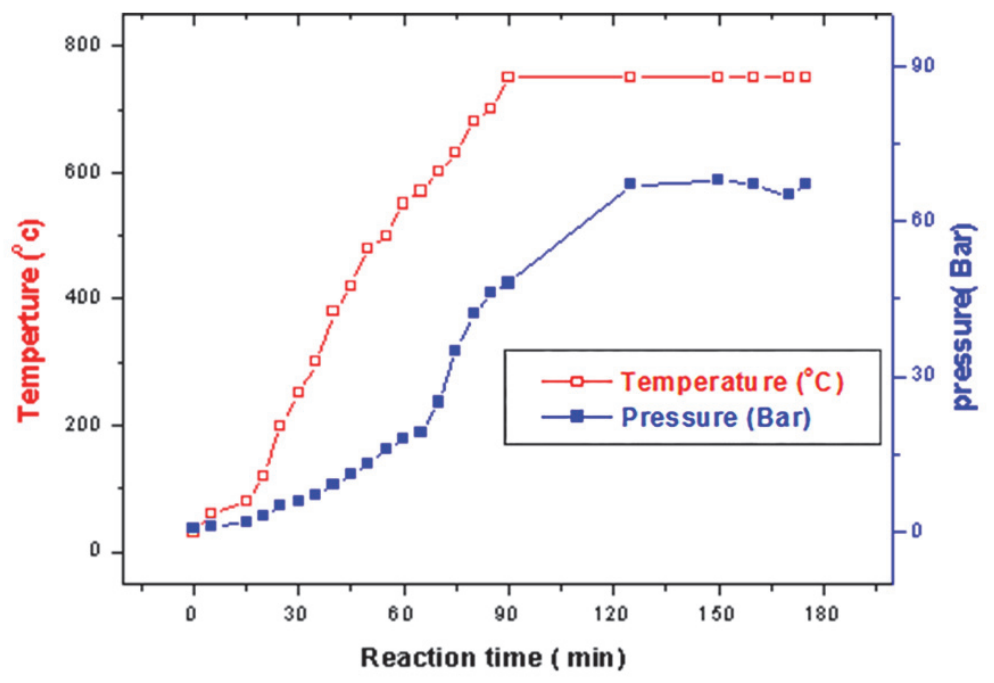

Figure (5). Profile of temperature and pressure against time for the gasification reaction

\subsubsection{Effect of Temperature on Gasification Process}

One important factor in the gasification process is temperature and also, that determine the relative yields of the products (Bridgwater, 2012). By studying the effect of temperature from $400^{\circ} \mathrm{C}$ to $900^{\circ} \mathrm{C}$ for 1 hour on the degradation of poly ethylene high density, we get the product distribution of gas yield and char. This is seen in fig6. As long as the gasification temperature increases from $450^{\circ} \mathrm{C}$ to $750^{\circ} \mathrm{C}$, the gas yield increases from $0.58 \mathrm{~m}^{3} / \mathrm{kg}$ to $0.98 \mathrm{~m}^{3} / \mathrm{kg}$. It then decreases at $750^{\circ} \mathrm{C}$ to $0.9 \mathrm{~m}^{3} / \mathrm{kg}$. While char is recorded as a high value at $550^{\circ} \mathrm{C}$, it slowly decreases to 38.2 and that demonstrates a complete conversion of plastic to gas at this range of heat. 


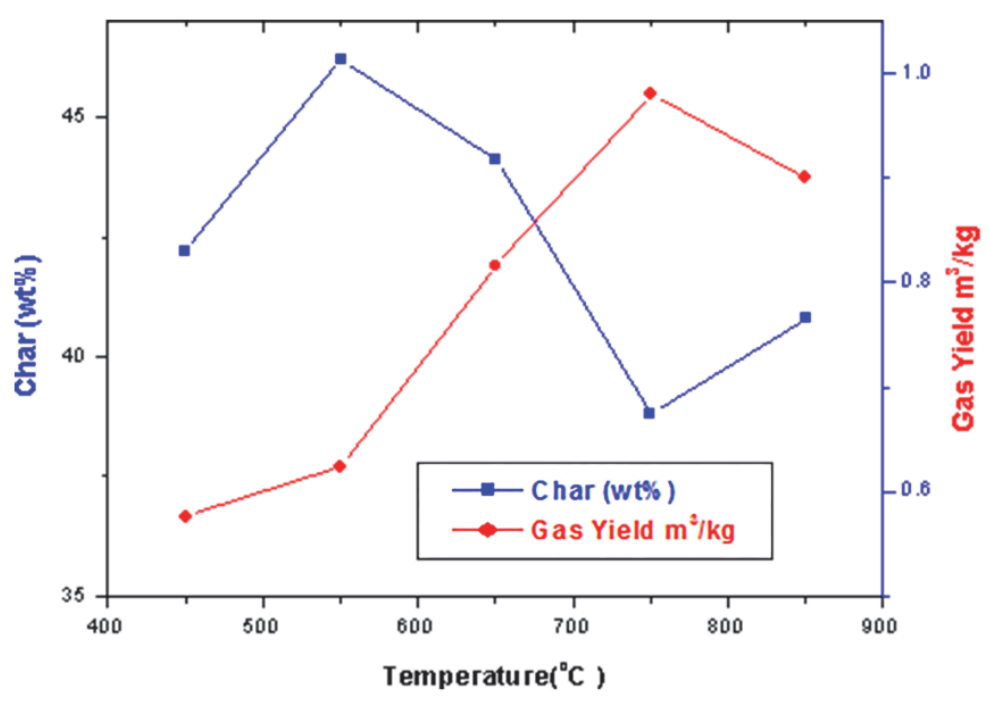

Figure (6). Effect of temperature on the gasification of polyethylene (PEHD; Reaction time: 60min

\subsubsection{Evaluating the Feeding Ratio of Modified Catalysts (Composite Catalyst) on the Gasification of PEHD.}

In this study, we tried to get the best feeding ratio of the catalyst $\left(\mathrm{MnO}, \mathrm{ZnO}, \mathrm{TiO}_{2}-\mathrm{Bn}\right)$ at $750^{\circ} \mathrm{C}$ for one hour. So we conducted our experiments with different ratios of the composite catalyst and plastic sample (PEHD) $(0: 1$, 0.008:1, 0.02:1, 0.04:1 and 0.06:1) in a gasified fixed reactor. Results are shown in fig-7. So, the best ratio for the composite catalyst is $0.04: 1$ which is clear in quantity of gas yield and char\%. This means there is complete cracking conversion of PEHD to fuel. The gas yield value slightly increased from $0.26 \mathrm{~m} 3 / \mathrm{kg}$ at $6 \%$ used catalyst to $0.94 \mathrm{~m} 3 / \mathrm{kg}$ at $4 \%$. Also, the char ratio changed with a different feeding ratio of catalysts. We got less amount of char (18.2) with a catalyst ratio of $6 \%$ of its weight in the gasification process, and a high amount of char (55.3) with $2 \%$ catalyst. it was the least amount \%t 6 of weighting the same catalyst. This means PEHD was not completely converted during the gasification process. From the data analysis, we found that the best ratio of the feeding catalyst in the process is $4 \%$. Since it gave a high ratio of gas yield and an acceptable amount of char ,this proves there is good catalytical cracking for PEHD related to Le Chateliers' principle. Higher temperatures favor the reactants in exothermic reactions and the products in endothermic reactions. The main reactions are endothermic.

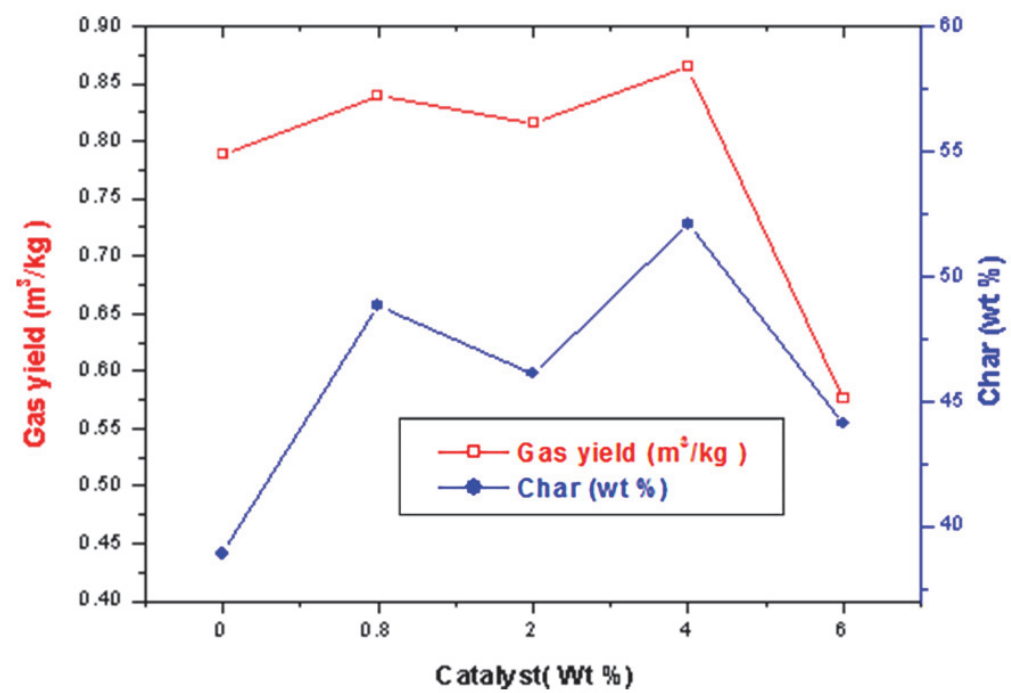

Figure (7). Studying the optimized feeding ratio for modified catalysts on the gasification of PEHD at $750{ }^{\circ} \mathrm{C}$ for 


\subsection{Study and Evaluation Modified Catalysts at Optimize Conditions on Plastic Gasification Process.}

\subsubsection{Gasification Process of Virgin Polyethylene High Density (PEHD)}

Applying modified catalysts on PEHD gave good results as shown in fig- 8 . There were optimized conditions (temperature was $750^{\circ} \mathrm{C}$, reaction time was 1 hour and loading composite catalyst was $4 \%$ ). Through the experiment, we noticed that char conversion for $\mathrm{TiO}_{2}-\mathrm{Bn}$ is lower than other modified catalysts but more than PEHD and bentonite alone. On the other hand, compared to $\mathrm{ZnO}-\mathrm{Bn}$, there was a high ratio of carbon char conversion (68.6\%) and gas yield (94). This proves that the electron movement in the d- orbital may create oxidation states number the $\mathrm{MnO}_{2}$ and $\mathrm{ZnO}$ with Bentonite. In conclusion, the best ratio of gas yield (1.02) is given by modified bentonite with three metal oxides $\left(\mathrm{TiO}_{2}, \mathrm{MnO}\right.$ and $\left.\mathrm{ZnO}\right)$, adding to the carbo char conversion (67\%). This means there is good coordination bonding between the free electron in configuration d Orbital and the ion exchange in Bentonite sheets. This affects the activation energy of the reaction.

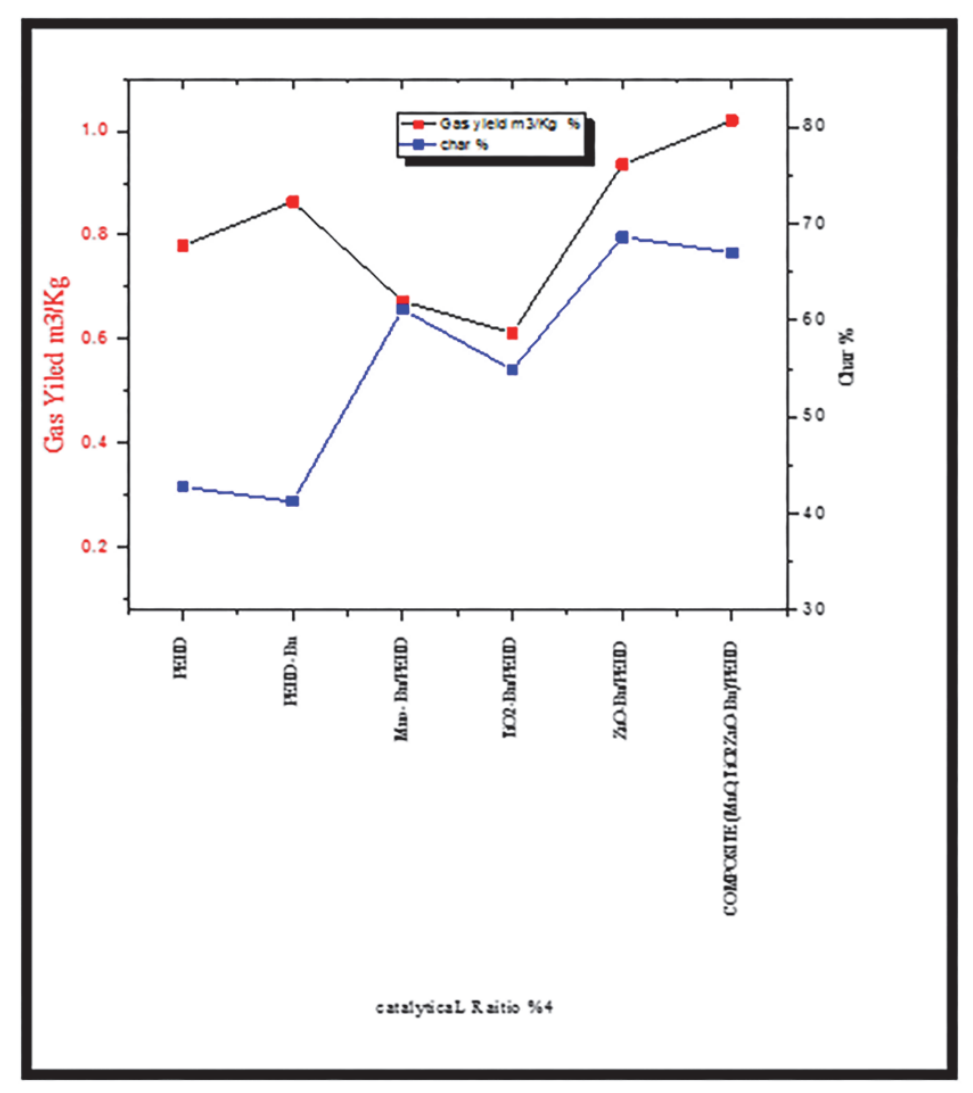

Figure (8). Effect of modified catalysts on gasification of PEHD at $750{ }^{\circ} \mathrm{C}$ for 1 hour

\subsubsection{Gasification Process on Waste Polyethylene High Density}

Figure (9) explains the gas yield and char components resulting from the degradation of polyethylene high density waste. from results, also, we noticed composite catalyst gave better results than the others at the same reaction conditions. Meanwhile, noticed the $\mathrm{ZnO} / \mathrm{Bn}>\mathrm{MnO} / \mathrm{Bn}>\mathrm{TiO}_{2} / \mathrm{Bn}$ for gas yield 


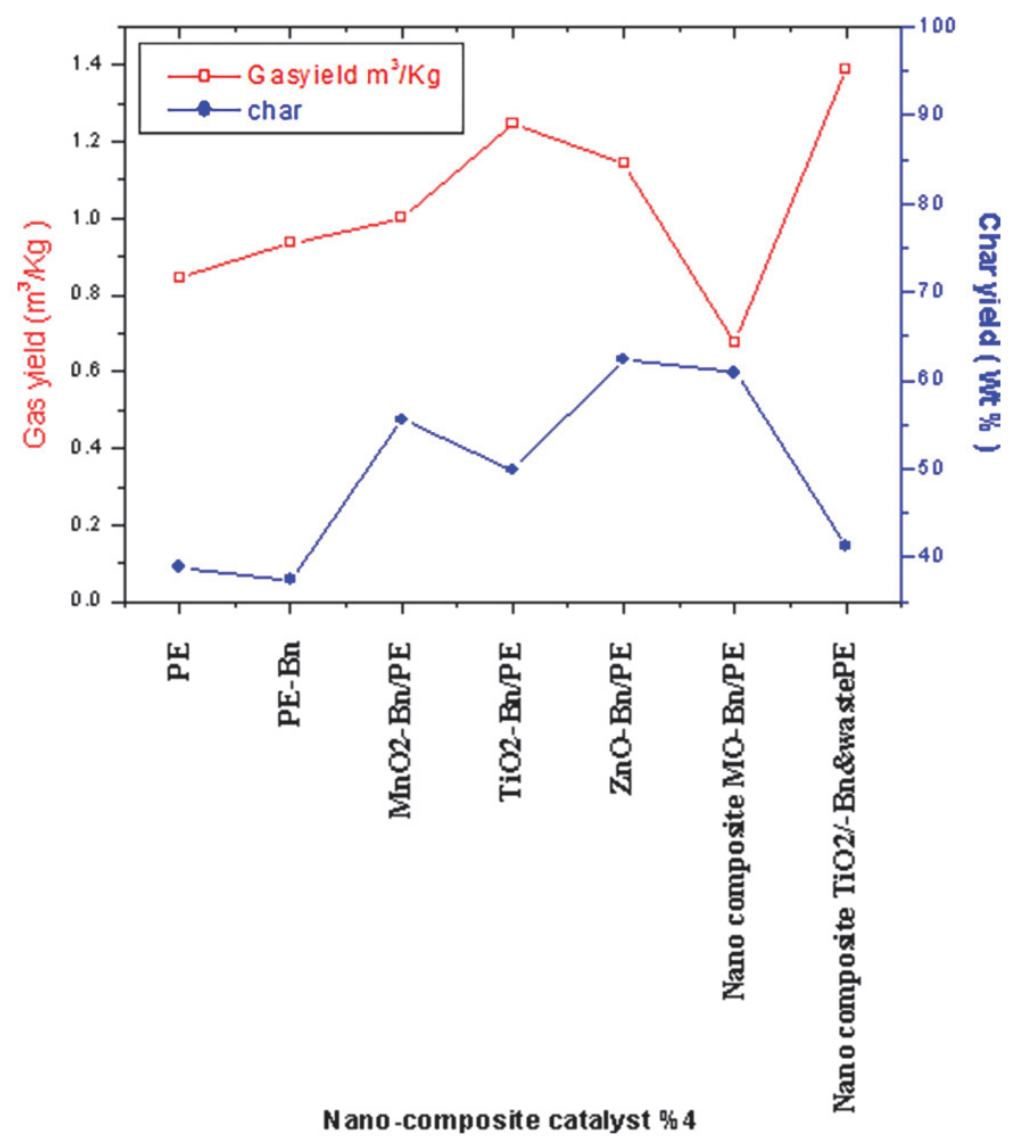

Figure (9). Gasification of Waste PEHD at optimize reaction conditions

\subsubsection{Gasification of Different Types Plastic Waste}

when, we applied the same optimize condition (reaction time for one hour, loading catalyst is $\% 4$ and temperature is constant at $750^{\circ} \mathrm{C}$ ) on degradation of different sorts of plastic waste like (PELD, PP, PVC, PS,), we get less quantities of (gas yield and char) comparing to virgin PEHD.that is shown in figure (10), might be due to contamination of different plastic, or there wasn't complete conversion for plastic at those parameters (temperature, reaction time and loading catalyst). 


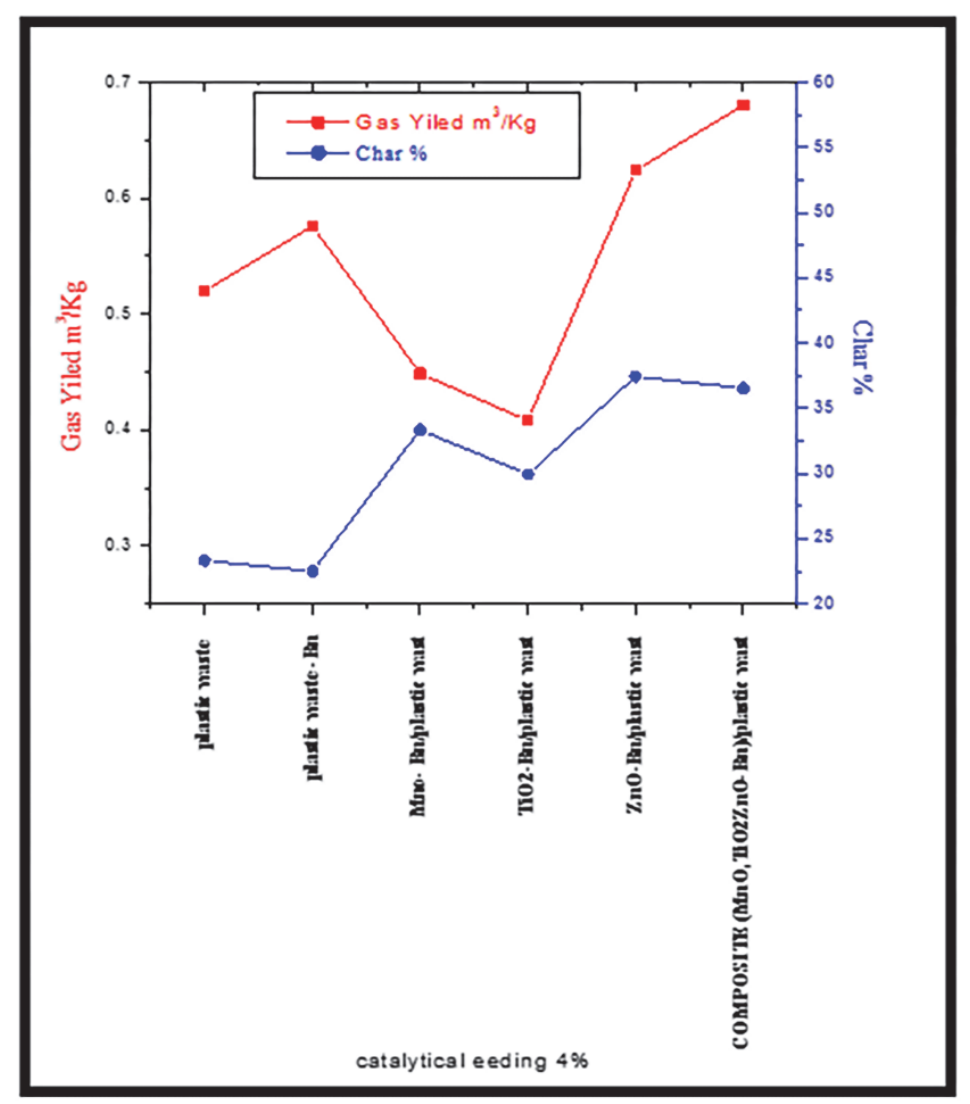

Figure (10). Gasification of Different sorts plastic Waste at optimize reaction conditions.

\subsection{Characterization of Gas Yield Distribution, Products of Gasification PEHD and Waste}

\subsubsection{GC Analysis for PEHD Gas Yield Distribution Products}

Char and gas samples resulting from the degradation of plastic waste at different conditions during the gasification process were analyzed by a variety of characterization techniques at the Central Analytical Laboratories of National Research Centre in Egypt. One technique used was elemental analysis (CHNSO elemental, Vario EL III). Gaseous products were analyzed using a Gas Chromatograph (VARIAN model CP-3800) at the Egyptian Petroleum Research Institute (EPRI) in Egypt.

On the other hand, analyzing the gases resulting from the degradation of plastic using GC, many components were detected such as aromatic, light olefin, methane gas, $\mathrm{CO}, \mathrm{CO}_{2}$, and $\mathrm{H}_{2}$ as shown in table (1). Thus, modified catalysts play an important role not only in gas yield quantity but also in the quality of product. The creaking process (catalytic process) occurred with different catalysts. This demonstrated positive results reforming with different quantities of gas product. The main product in the gasification process is Methane that can be used as a source of energy. 
Table (1) Major product distributions for the gasification process of PEHD and its waste at $4 \%$. at different modified catalytic at $750{ }^{\circ} \mathrm{C}$ and a reaction time of 1 hour.

\begin{tabular}{|c|c|c|c|c|c|c|c|}
\hline \multirow[b]{2}{*}{ (Mol. \%) } & \multirow[b]{2}{*}{$\begin{array}{l}\text { Without } \\
\text { catalyst }\end{array}$} & \multicolumn{6}{|c|}{ With catalyst $0.4 \mathrm{wt} \%$} \\
\hline & & Bn & $\mathrm{Bn} / \mathrm{TiO}_{2}$ & $\mathrm{Bn} / \mathrm{MnO}$ & $\mathrm{Bn} / \mathrm{ZnO}$ & $\begin{array}{c}\text { Composite } \\
\mathrm{TiO}_{2}, \mathrm{MnO}_{2}, \mathrm{ZnO} / \mathrm{Bn} \\
\text { \& PEHD }\end{array}$ & $\begin{array}{c}\mathrm{TiO}_{2}, \mathrm{MnO}_{2}, \mathrm{ZnO} / \mathrm{Bn} \\
\text { \&waste } \mathrm{PEHD}\end{array}$ \\
\hline Methane & 83.41 & 83.29 & 85 & 88.91 & 89.7 & 96.34 & 89.55 \\
\hline Hydrogen & 0.88 & 2.61 & 4.87 & 1.53 & 0.63 & 2.93 & 0.001 \\
\hline Benzene & 0.95 & 0.85 & 0.04 & 0.23 & 0.27 & .004 & 0.23 \\
\hline $\begin{array}{l}\text { Carbon } \\
\text { Dioxide }\end{array}$ & 2.37 & 3.5 & 4.92 & 2.70 & 2.89 & 0.22 & 0.16 \\
\hline Nitrogen & 3.2 & 3.12 & 0.58 & 0.44 & 0.83 & 0.17 & 3.6 \\
\hline Ethane & 4.56 & 1.75 & 0.59 & 4.21 & 4.03 & 0.08 & 4.5 \\
\hline $\begin{array}{c}\text { Carbon } \\
\text { Monoxide }\end{array}$ & 3.4 & 3.89 & 3.47 & 0.96 & 0.42 & 0.20 & 1.18 \\
\hline
\end{tabular}

The best methane ratio is 96.34 by $\mathbf{T i O}_{2}, \mathbf{M n O}, \mathbf{Z n O} / \mathbf{B n}$ \& $\mathbf{P E H D}$ compared to $83.4 \mathrm{Bn}$ without. We obtained an excess amount of Hydrogen (4.87) as given by the $\mathbf{B n} / \mathbf{T i O} \mathbf{O}_{2}$ catalyst in fig-10. that is can used in fuel cell in future studies, prove that , the activity of $\mathrm{TiO}_{2} / \mathrm{Bn}$ which can make a coordination bond with the ligand and result in many products through the gasification process, such as Benzene, $\mathrm{CO}$ and char.

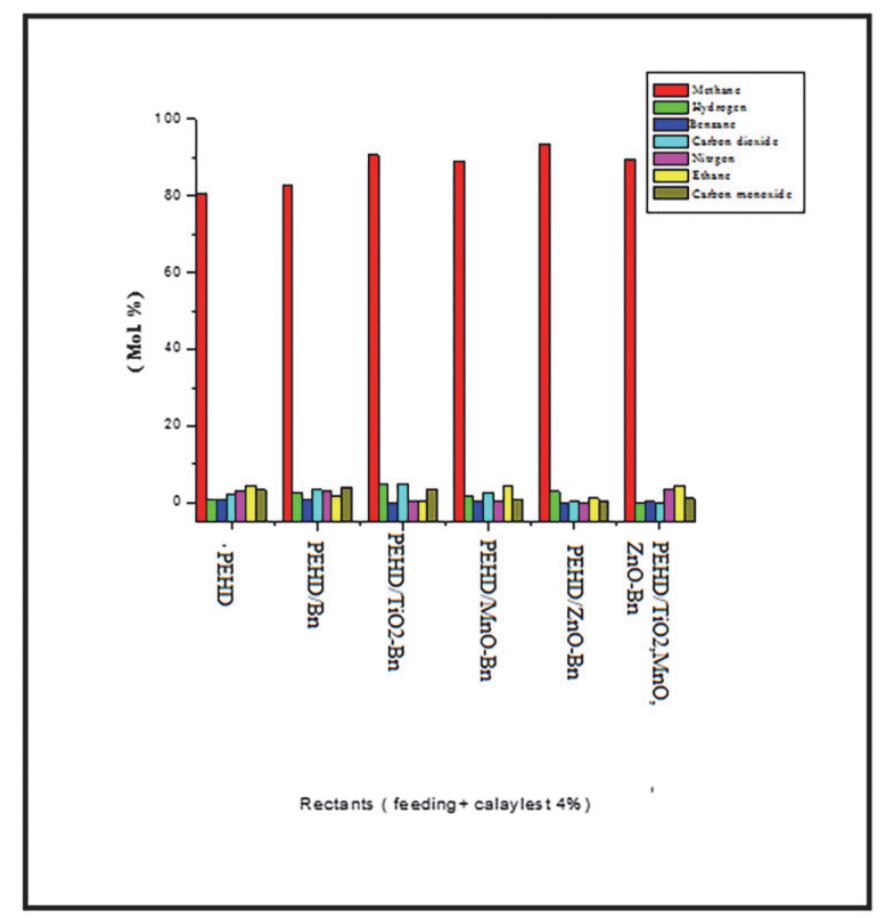

Figure (10). Product distribution of gasification of PEHD using different modified catalysts at $750{ }^{\circ} \mathrm{C}$ for 1 hour 
3.4.2 GC Analysis Gas Yield Distribution Products Resulting from for Gasification of Different Plastic Waste (PW) when analyzing the sample results for the gasification of degradation of different plastic waste (PW), we got good results but they are less than in the virgin PEHD and its waste. This is explained in table -2 . There is a high ratio of methane gas from plastic waste according to $\mathrm{Bn}\left(\mathrm{TiO}_{2}\right)>\mathrm{Bn}(\mathrm{ZnO})>\mathrm{Bn}$ (metals oxides) $>\mathrm{Bn}(\mathrm{MnO})>\mathrm{Bn}$.

Table (2) Major product distribution for the gasification process of plastic waste (PW) at $4 \%$ at different modified catalytic at $750^{\circ} \mathrm{C}$ and a reaction time for 1 hour.

\begin{tabular}{|c|c|c|c|c|c|c|c|}
\hline \multirow[b]{2}{*}{ ( Mol. \%) } & \multirow[b]{2}{*}{ WP } & \multicolumn{6}{|c|}{ With catalyst 0.4 wt $\%$} \\
\hline & & Bn-WP & $\begin{array}{c}\text { Bn-TiO } \\
\text { WP }\end{array}$ & $\begin{array}{c}\mathrm{Bn} / \mathrm{MnO} / \\
\text { WP }\end{array}$ & $\begin{array}{c}\mathrm{Bn} / \mathrm{ZnO} / \\
\mathrm{WP}\end{array}$ & $\begin{array}{l}\text { CompositeTiO }_{2}, \mathrm{Mn} \\
\mathrm{O}, \mathrm{ZnO} / \mathrm{Bn} \& \text { WP }\end{array}$ & $\begin{array}{c}\text { Composite } \\
\mathrm{TiO}_{2}, \mathrm{MnO}_{2}, \mathrm{ZnO} / \mathrm{Bn} \\
\text { \& Waste plastic }\end{array}$ \\
\hline Methane & 80.41 & 82.94 & 90.6 & 88.91 & 89.7 & 93.63 & 89.55 \\
\hline Hydrogen & 0.79 & 2.61 & 1.24 & 1.53 & 0.66 & 2.88 & 0.001 \\
\hline Benzene & 0.95 & 0.88 & 0.06 & 0.23 & 0.34 & 0.05 & 0.23 \\
\hline $\begin{array}{l}\text { Carbon } \\
\text { Dioxide }\end{array}$ & 3.15 & 3.6 & 3.88 & 2.70 & 2.90 & 0.22 & 0.16 \\
\hline Nitrogen & 3.6 & 3.4 & 3.06 & 0.44 & 0.86 & 0.17 & 3.6 \\
\hline Ethane & 4.5 & 1.82 & 0.55 & 4.21 & 4.06 & 1.08 & 4.5 \\
\hline $\begin{array}{l}\text { Carbon } \\
\text { Monoxide }\end{array}$ & 3.4 & 3.89 & 3.47 & 1.01 & 0.82 & 0.22 & 1.18 \\
\hline
\end{tabular}

Also, comparing other components of gases $\left(\mathrm{H}_{2}\right.$, Benzene), we found a great ratio with the modified catalyst. In addition, there was less amount of $\mathrm{CO}$ and $\mathrm{CO}_{2}$ which shows that there was complete conversion of plastic to gas (Levine and Broadbelt (2009) and Kannan et al. (2014).Figure (10): Product distribution of gasification of PEHD using different modified catalysts at $750{ }^{\circ} \mathrm{C}$ for 1 hour. 


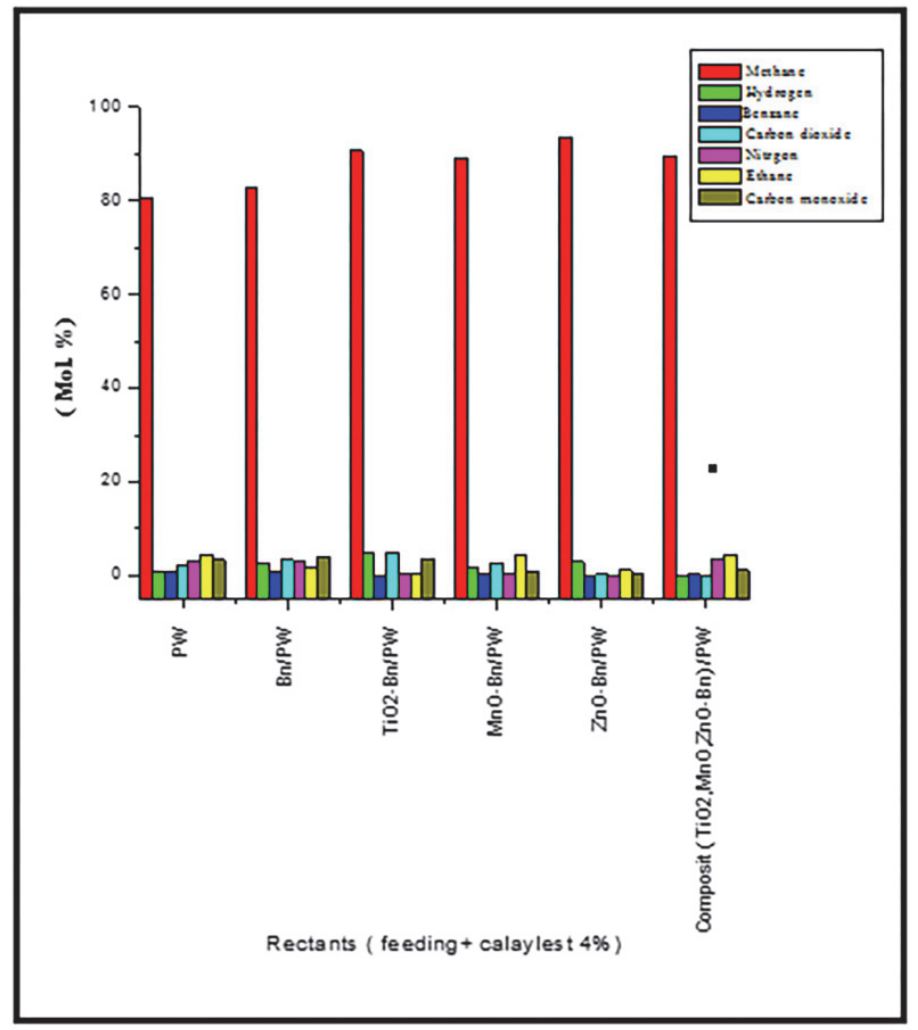

Figure (11). Product distribution of the gasification of waste plastic (PW) using different modified catalysts at $750^{\circ} \mathrm{C}$ for 1 hour

\subsection{Characterization of the Char Resulting of Gasified PEHD.}

\subsubsection{Scanning Electron Microscopy (SEM)}

Scanning electron microscopy (SEM) was used to illustrate the surface morphologies of the prepared samples. The surface morphologies of the char product in Fig-12 showed irregular and sharp-edged properties (W. D. KELLER et al 1986). The char exhibited porous and textural structure characteristics. The char consisted of small, relatively uniform particles and each particle was smooth and compressed. The surface morphologies of the char contained modified Bentonite composite as shown in Fig-12. A significant difference in morphology can be seen for the char. The char's surface was smooth and compact. No obvious pore structure were found in the char's surface, which might be attributed to the agglomeration and melting during the gasification of plastic. which manifest by EDAX analysis.

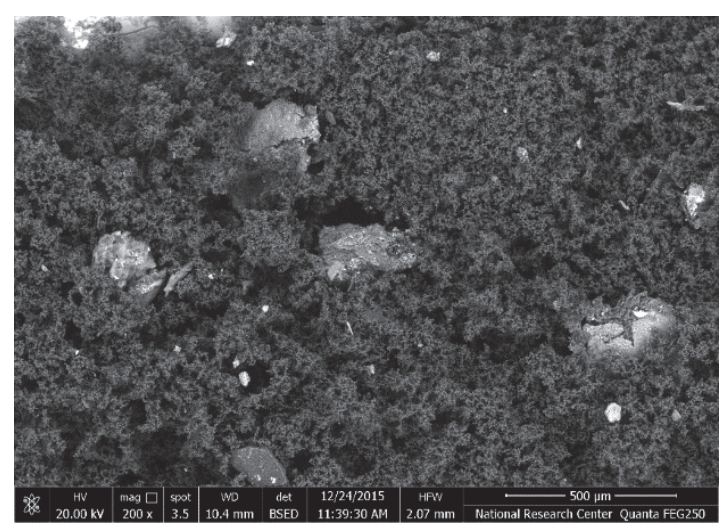

Figure (12). SEM image of the char sample gasification of polyethylene high density at $750^{\circ} \mathrm{C}$ for $1 \mathrm{hr}$. 


\subsubsection{Energy-Dispersive X-Ray Spectroscopy (EDX)}

(EDX) confirmed the results of SEM. by analysis char sample which resulted from the gasification process. After analyzing the sample, it was clear that it has the same chemical composition of modified bentonite seen in fig- 13 . This proves that the new modified catalyst has good and maybe more stability in high temperatures like $750{ }^{\circ} \mathrm{C}$.

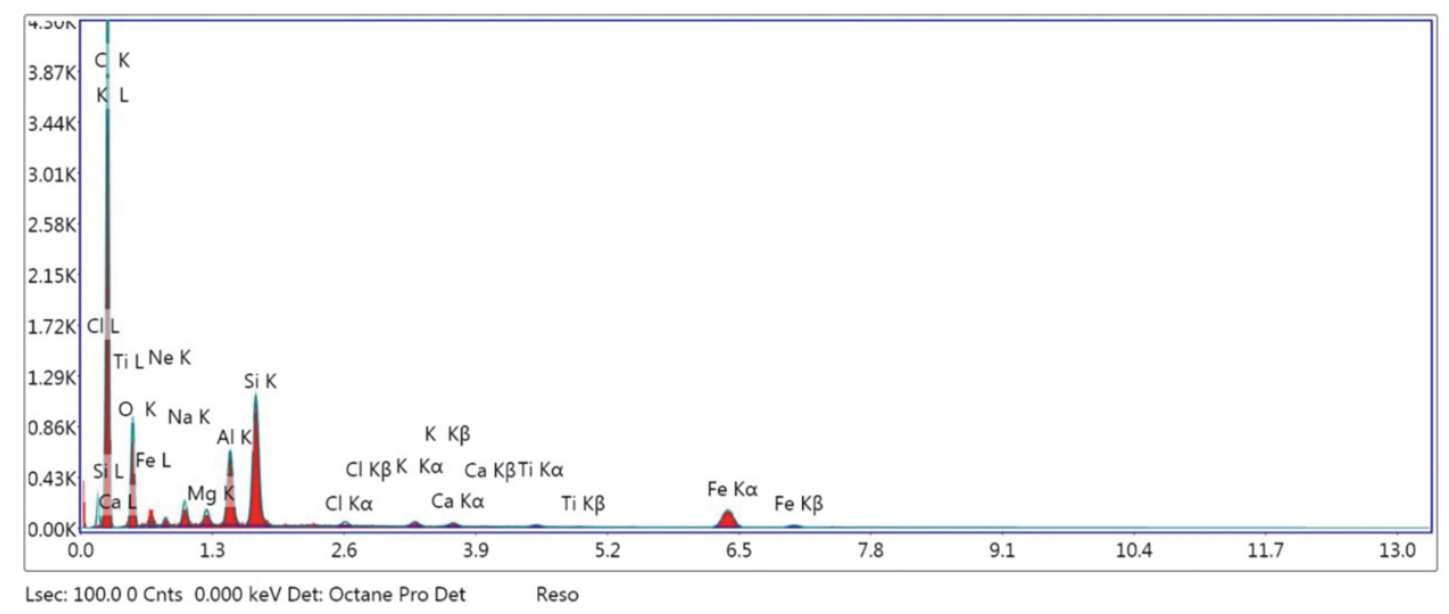

Figure (13). EDAX of catalytically pyrolysis HDPE Char with modified composite bentonite

\subsubsection{Elemental Analysis}

Proximate and ultimate analysis of virgin HDPE. The proximate and ultimate analysis of the virgin PEHD sample before and after the gasification process (char sample) is shown in Table (3). First, in the sample before gasification, the volatile matter is $100 \%$ in the proximate analysis. Due to the negligible percentage of ash in the virgin HDPE sample, its degradation occurs with minimal residue formation. The oxygen is $2.51 \%$ in the ultimate analysis of virgin HDPE. The nitrogen and oxygen in the virgin PEHD sample may not be due to the fillers but because of different components added during the fabrication of PEHD. Also, we can refer to Table (3) which illustrates the comparison between the proximate and ultimate PEHD after the gasification process. The ratio element H, C, N and S composition compounds were completely changed. Due to many factors, one of them is modified composite during of gasification process. On the other hand, this demonstrates conversion of PEHD due to the large quantity of $\mathrm{C} \%$ transformed during the gasification process. Furthermore, $\mathrm{H} \%$ changed from $14.1 \%$ to $3.45 \%$ which confirmed the complete conversion process for PEHD during the gasification process.

Table (3). Proximate and ultimate analysis of PEHD before and after the gasification process

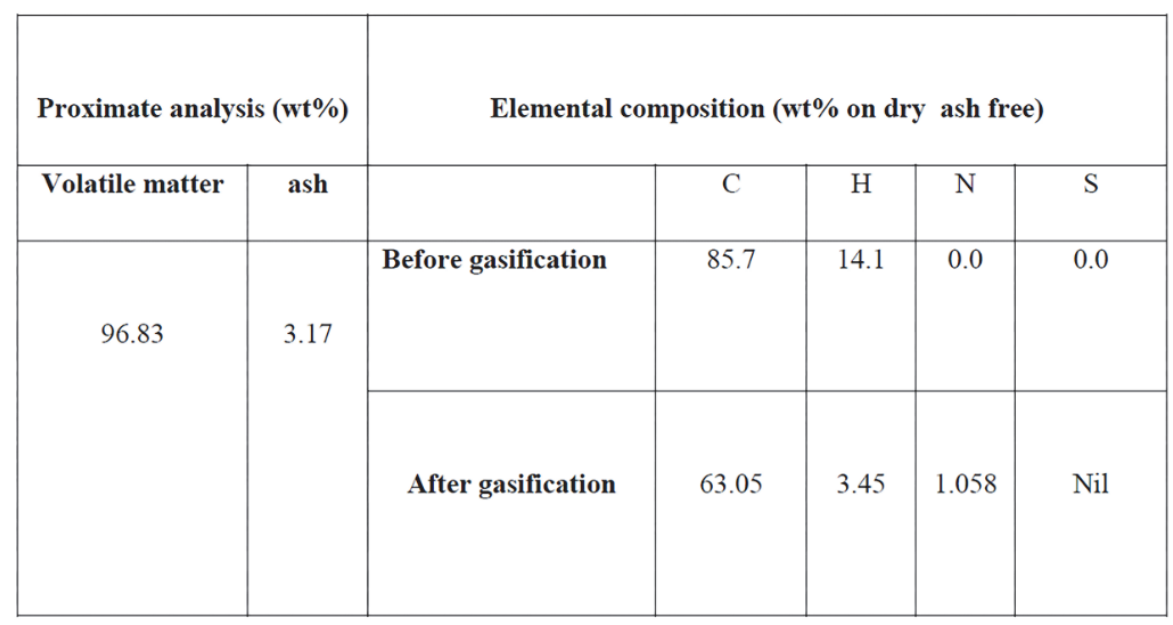




\section{Discussion.}

Through our experiment, we noticed many important points which open the door for researchers in the future. Metal transition is variable oxidation states that means make coordination compounds (complexes) and organometallic compounds is easier than other elements in addition to increase the surface area of reaction and decrease activation energy of reaction ,Further, we used three different metal oxides $\left(\mathrm{TiO}_{2}, \mathrm{MnO}\right.$ and $\left.\mathrm{ZnO}\right)$ which ARE subdivided into groups - D (different electronic configurations for each element) and explain how made chelating complex with clay (geo-polymer).

In addition, reactor design and setting up for pyrolysis and gasification process in add to choose the ideal parameters (reaction time, temperature and catalyst ratio).Optimized parameters gave good results for converting plastic waste and plastic PEHD to fuel. Also, we approached many scientific points like the reaction mechanism poly ethylene high density on gasification process with studying the effect of Nano transition metals oxides in modification clay through better results than using Bentonite without any additives.

Nano clay composites gave a gas yield $\left(\mathrm{CH}_{4}\right)$ and other light components is higher than other using modified catalysts. On the other hand, catalysts like $\mathrm{MnO}_{2} / \mathrm{Bn}$ gave a higher amount of Hydrogen than other catalysts. Also, there were excellent results with $\mathrm{TiO}_{2} / \mathrm{Bn}$ and different types of plastic (PEHD and Waste). One important thing is that ideal parameters for that reaction are the temperature at $750^{\circ} \mathrm{C}$ and reaction time not more than one hour. This helps to get a higher yield of light olefins, methane, Hydrogen and aromatic compounds. Furthermore, the catalyst also affects single-ring aromatic compounds by increasing their yield when this variable is increased. Also, the heating rate had a lower effect on the activation energy in our conditions. The heating rate does not significantly affect the char production although the char content tended to be less with a high heating rate. The gas yield ratio with the virgin PEHD is higher than other waste plastic. Although the reaction conditions are the same, may be return to some additive or contamination which has a great effect on the reaction mechanism of new composite catalysts. The results from different plastic waste is lower than virgin PEHD.

All in all, energy recovery from waste (renewable source) is enough to use in energy generation. beside to gasification or pyrolysis process is a good way to get rid of massive solid waste which takes hundred years to decay. The landfill process also has a negative impact in underground water in future and incineration is the main reason for carbon dioxide emission and climate change.

Using new modified materials is one of the most sustainable resources for converting plastic waste to fuel (source of renewable energy). In addition, it reduces the cost of production in the petroleum refining industry. The discussion includes different types of clay and clay-modified catalysts. The mechanism and results will open new opportunities for applying geopolymers in different fields.

Applying modified catalysts on a high temperature has many advantages. First, the thermal and catalytical cracking of polymers occur in high temperatures. It's also easier for condensed gas to flow in the pipeline, better than tar or asphalt (the result at a low temperature) which plugs the pipeline. This is a big problem in the production process. Also, we take into consideration the reaction time which verses proportion with temperature (increase activation energy of reaction). On the other hand, the modified catalyst carried out at a high temperature or $750{ }^{\circ} \mathrm{C}$ is the ideal temperature for a reaction with a time of 1 hour for the complete conversion of plastic to gas. This means it has stability and strong coordination bonds in composition.

Getting a good product distribution from plastic waste (low-value energy) with a modified catalyst to a high energy value like Methane is a high ratio. Hydrogen and other hydrocarbon compounds.

\section{Acknowledgement}

I wish to acknowledge the inputs and contributions of a number of persons who helped me in diverse ways to bring this paper to fruition.

\section{References}

Al-Salem, S. M., Lettieri, P., \& Baeyens, J. (2009). Recycling and recovery routes of plastic solid waste (PSW): a review. Waste Manage, 29, 2625-2643.

Baker, E. G., Mudge, L. K., \& Brown, M. D. Steam (1987). Gasification of biomass with nickel secondary catalysts. Ind Eng Chem Res., 26, 1335-1339.

Bockhorn, H., Hornung, A., Hornung, U., \& Jakobstroer, P. (1999). Modeling of isothermal and dynamic $€$ pyrolysis of plastics considering non-homogeneous temperature distribution and detailed degradation mechanism. J Anal Appl Pyrol., 49, 53-74.

Centi, G., \& Perathoner, S. (2008). Microporous and Mesoporous Materials, 107, 3. 
Chen, M. Q., Wu, L. X., Wang, W. K., Fan, M. Y., Zhang, Y. X., \& Tang, H. T. (2015). A Catalytic Cracking Method and Device for Double-Riser. Patent CN 104513673

Choi, J. H., Jeong, K. J., Dong, Y. J., Han, J. H., Lim, T. H., Lee, J. S., \& Sung, Y. E. (2006). Electro-oxidation of methanol and formic acid on PtRu and PtAu for direct liquid fuel cells. J. Power Sources, 163, 71-75.

Clay Minerals_-Sci-Tech Encyclopedia, (2007). McGraw Hill, Home Page: www.answers.com, accessed July 9

Clay Minerals-Sci-Tech Encyclopedia, McGraw Hill, Home Page: www.answers.com, accessed July 9, 2007.

Clay Minerals_-Sci-Tech Encyclopedia, McGraw Hill, Home Page: www.answers.com, accessed July 9, 2007.

Closite R Additives, Nano-Scale Additives for Reinforced Plastics, Southern Clay Products Inc., Austin, TX.

Comolli, A. G., Lee, L. K., \& Pradhan, V. (1997). Alternate fuels from the co-liquefaction of coal, oil, and waste plastics. Prepr.Pap.- Am. Chem. Soc., Div. Fuel Chem, 42(2), 736-740.

De Stefanis, A., \& Tomlinson, A. A. G. (2006). Towards designing pillared clays for catalysis. Catal. Today, 114, 126.

Ding, Z., Kloprogge, J. T., \& Frost, R. L. (2001). Porous clays and pillared clays-based catalysts. Part 2: A review of the catalytic and molecular sieve applications. J Porous Mater, 8, 273-293

Dutta, D. K., Borah, B. J., \& Sarmah, P. P. (2015). Recent advances in metal nanoparticles stabilization into nanopores of montmorillonite and their catalytic applications for fine chemicals synthesis. Catal. Rev., 57, 257-305.

Faravelli, T., Bozzano, G., \& Scassa, C., et al. (1999). Gas product distribution from polyethylene pyrolysis. $J$ Anal Appl Pyrol., 52, 87-103.

Faravelli, T., Bozzano, G., Colombo, M., Ranzi, E., \& Dente, M. (2003). Kinetic modeling of the thermal degradation of polyethylene and polystyrene mixtures. J Anal Appl Pyrol., 70, 761-777.

Galamboš, M., Kufcáková, J., \& Rajec, P. (2009). Adsorption of cesium on domestic bentonites. Journal of Radioanalytical and Nuclear Chemistry, 281(3).

Gilman, J. W., Kashiwagi, T., Morgan, A. B., Harris, Richard, H. Jr., Brassell, L., Vanlandingham, M., J., \& Catheryn, L. (1999). National Institute of Standards and Testing (NIST), "Flammability of Polymer Clay Nanocomposites page 25.

Herrero, J., Blanco, C., Esteruelas, M. A., \& Oro L A. (1990). ApplOrganometalChem, 4, 157.

Hettinger, W. P. Jr. (1991). Contributions to catalytic cracking in the petroleum industry. Appl. Clay Sci., 5, 445468.

International Journal of Chemistry and Chemical Engineering (IJCCE). ISSN 2248-9924... The Journal welcomes original research contributions from all established areas of chemistry (pure and applied) and chemical... Vol. 1 No.1. (2012). bullet. Vol. 2 No.1 bullet. Vol. 3 No.1 No.2 (2013).

Kannan, P., Shoaibi, A. A., \& Srinivasakannan, C. (2014). Temperature effects of the yield of gaseous olefins from waste polyethylene via flash pyrolysis. Energy Fuels, 28, 3363-3366.

Kassim, A. N. J. (2015). Synthesis of Zinc Oxide Nanoparticles via Sol - Gel Route and Their Characterization, $5(1), 1-6$.

Keller, W. D., Reynolds, R. C., \& Atsuyuki, I. (1986). Morphology of Clay Minerals in The Smectite-To-Illite Conversion Series by Scanning Electron Microscopy. Clays and Clay Minerals, 34(2), 187-197.

Kruse, T. M., Levine, S. E., \& Wong, H. W, et al. (2005). Binary mixture pyrolysis of polypropylene and polystyrene: a modeling and experimental study. J Anal Appl Pyrol, 73, 342-354.

Kruse, T. M., Wong, H W., \& Broadbelt, L J. (2003). Mechanistic modeling of polymer pyrolysis: polypropylene. Macromolecules, 36, 9594-9607.

Kruse, T. M., Woo, O. S., \& Broadbelt, L. J. (2001). Detailed mechanistic modeling of polymer degradation: application to polystyrene. Chem Eng Sci., 56, 971-979.

Kruse, T. M., Woo, O. S., Wong, H. W., Khan, S. S., \& Broadbelt, L. J. (2002). Mechanistic modeling of polymer degradation: a comprehensive study of polystyrene. Macromolecules, 35, 7830-7844.

Kuo-Tseng, Li, Ikai W., \& Jung, Ch. W. (2012). Surface and Catalytic Properties of TiO2-ZrO2 Mixed Oxides. Catalysis Surveys from Asia, 16(4), 240-248. 
Lazarevic, D., Aoustin, E., Buclet, N., \& Brandt, N. (2010). Plastic Waste management in the context of a European recycling society: comparing Results and uncertainties in a life cycle perspective. Resour Conserv Recycl, 55, 246-259.

Levine, S. E., \& Broadbelt, L. J. (2008). Reaction pathways to dimer in polystyrene pyrolysis: a mechanistic modeling study. Polym Degrad Stabil, 93, 941-951.

Levine, S. E., \& Broadbelt, L. J. (2009). Detailed mechanistic modeling of high-density polyethylene pyrolysis: low molecular weight product distribution. Polym Degrad Stabil, 94, 810-822.

Liu, C., Wang, H., Karim, A. M., Sun, J., \& Wang, Y. (2014a.). Catalytic fast pyrolysis of lignocellulosic biomass. Chem Soc Rev., 43, 7594-7623.

Marongiu, A., Faravelli, T., \& Ranzi, E. (2007). Detailed kinetic modeling of the thermal degradation of vinyl polymers. J Anal Appl Pyrol, 78, 343-362.

Marongiu, A., Faravelli, T., Bozzano, G., Dente, M., \& Ranzi, E. (2003). Thermal degradation of poly(vinyl chloride). J Anal Appl Pyrol, 70, 519-553.

MURRAY, H. H. (1997). Applied clay mineralogy today and tomorrow Department of Geological Sciences, Indiana University, Bloomington, IN47405, USA.

Murray, H. H. (2007). Applied clay mineralogy. 1stedition, Copyright (C) 2007, Elsevier B.V., ISBN-13: 978-0444-51701-2.

Poutsma, M. L. (2003). Reexamination of the pyrolysis of polyethylene: data needs, free-radical mechanistic considerations, and thermochemical kinetic simulation of initial product-forming pathways. Macromolecules, 36, 8931-8957.

Poutsma, M. L. (2005). Comparison of literature models for volatile product formation from the pyrolysis of poluisobutylene at mild conditions: data analysis, free-radical mechanistic considerations, and simulation of initial product-forming pathways. J Anal Appl Pyrol, 73, 159-203.

Poutsma, M. L. (2009). Further considerations of the sources of the volatiles from pyrolysis of polystyrene. Polym Degrad Stabil, 94, 2055-2064.

Rafat, S., Khatib, J., \& Inderpreet, K. (2008). Use of recycled plastic in Concrete: a review. Waste Manage, 28 , $1835-1852$.

Rao, Y., \& Blanton, T. N. (2008). Macromolecules, 41(3), 935-41.

Rebeiz, K. S., \& Craft, A. P. (1995). Plastic waste management in construction technological and institutional issues. Resour. Conserv.Recycl., 15, 245-257.

Riyadh, M., Alwan, Quraish, A., Kadhim, K. M., Sahan, R. A., Ali, R. J., Mahdi, N. A., Radwan, A. M., Hamad, M. A., \& Singedy, A. M. (2015) Synthesis gas production from catalytic gasification of saw dust. Journal article: Life Science Journal, 12(7), 104-118.

Semwal, S., Arora, A. K., Badoni, R. P., \& Tuli, D. K. (2011). Biodiesel production using heterogeneous catalysts. Bioresour. Technol, 102, 2151-2161.

Sharifzadeh, M., Wang, L., \& Shah, N. (2015). Decarbonisation of olefin processes using biomass pyrolysis oil. Appl. Energy.

Shen, Y., Xiao, K. J., Xi, J. Y., \& Qiu, X. P. (2015). Comparison study of few-layered graphene supported platinum and platinum alloys for methanol and ethanol electro-oxidation. J. Power Sources, 278, 235-244.

Tanaka, K. I. (2010). Unsolved problems in catalysis. Catal. Today, 154, 105-112.

Trilochan, M. (2010). Transition Metal Oxide-Pillared Clay Catalyst: Synthesis to Application. Pillared Clays and Related Catalysts, 99-128.

Tripkovic, A. V., Popovic, K. D., Grgur, B. N., Blizanac, B., Ross, P. N., \& Markovic, N. M. (2002). Methanol electrooxidation on supported Pt and PtRu catalysts in acid and alkaline solutions. Electrochim.Acta, 47, 3707-3714.

Turgutbasoglu, F., \& Balci, S. (2005). Improvements of catalytic properties of the pillared layered clays and investigation of catalytic activity in CO oxidation Proceedings of the 13th International Clay Conference, Waseda University, Tokyo, Japan, p. 55.

V1, Zhu, H., Vajtai, R., Ajayan, P. M., \& Wei, B. (2005). Hydrothermal synthesis and pseudocapacitance 
properties of MnO2 nanostructures. SubramanianJ Phys Chem B., 109(43), 20207-14.

Valentina, B., Helmuth, M., \& Dmitry, G. S. (2008). Sonochemical Intercalation of Preformed Gold. Nanoparticles into Multilayered Clays., 24(17), 9747-9753.

Van Swaaij, W. P. M. (1981). Gasification - the process and the technology. Resour Conserv, 7, 337-49.

Vassilev, S. V., Baxter, D., \& Andersen, L. K. (2010).CG: An overview of the chemical composition of biomass. Fuel, 89, 913-933.

Vermeiren, W., \& Gilson, J. P. (2009). Impact of zeolites on the petroleum and petrochemical industry. Top.Catal., $52,1131-1161$.

Vinu, R., \& Broadbelt, L. J. (2012b). Unraveling reaction pathways and specifying reaction kinetics for complex systems. Annu Rev Chem Biomol Eng., 3, 29-54.

Westerhout, R. W. J., Balk, R. H. P., Meijer, R., Kuipers, J. A. M., \& van Swaaij WMP. (1997b). Examination and evaluation of the use of screen heaters for the measurement of the high temperature pyrolysis kinetics of polyethene and polypropene. Ind Eng Chem Res., 36, 3360-3368.

Westerhout, R. W. J., Waanders, J., Kuipers, J. A. M., van Swaaij. W. M. P (1997a). Kinetics of the lowtemperature pyrolysis of polyethene, polypropene, and polystyrene modeling, experimental determination, and comparison with literature models and data. Ind Eng Chem Res., 36.

Williams, G. R., O’Hare, D. J., \& Mater, Chem. (2006). Towards understanding, control and application of layered double hydroxide chemistry. J. Mater. Chem., 16, 3065-3074.

Wolczanski, P. T., \& Chirik, P. J. (2015). A career in catalysis: John E. bercaw. ACS Catal. 5, 1747-1757.

Worldwatch Institute, Washington. (2016). DC: Global plastic production rises, recycling lags (website). http://www.worldwatch.org/global-plastic-production-rises-recycling-lags-0. Accessed (June).

Xiao, M. L., Feng, L. G., Zhu, J. B., Liu, C. P., \& Xing, W. (2015). Rapid synthesis of a PtRunano-sponge with different surface compositions and performance evaluation for methanol electrooxidation. Nanoscale, 7 , 9467-9471.

y Minerals-Sci-Tech Encyclopedia, McGraw Hill. Retrieved July 9, 2007, from www.answers.com

Yadav, G. D., \& Nair, J. J. (1999). Sulfated zirconia and its modified versions as promising catalysts for industrial processes. MicroporousMesoporous Mater, 33, 1-48.149, 404-414.

Yasukawa, T., Suzuki, A., Miyamura, H., Nishino, K., \& Kobayashi, S. (2015). Chiral metal nanoparticle systems as heterogeneous catalysts beyond homogeneous metal complex catalysts for asymmetric addition of arylboronic acids to $\alpha, \beta$-unsaturated carbonyl compounds. J. Am. Chem. Soc., 137, 6616-6623.

Zhang, S., Li, J., Gao, W., \& Qu, Y. Q. (2015). Insights into the effects of surface properties of oxides on the catalytic activity of $\mathrm{Pd}$ for $\mathrm{C}-\mathrm{C}$ coupling reactions. Nanoscale, 7, 3016-3021.

Zhang, S., Shen, X. T., Zheng, Z. P., Ma, Y. Y., \& Qu, Y. Q. (2015). 3D graphene/nylon rope as a skeleton for noble metal nanocatalysts for highly efficient heterogeneous continuous-flow reactions. J. Mater. Chem, 3, 1050410511.

Zhou, W. J., Zhou, Z. H., Song, S. Q., Li, W. Z., Sun, G. Q., Tsiakaras, P., \& Xin, Q. (2003). Pt based anode catalysts for direct ethanol fuel cells. Appl. Catal. B Environ., 46, 273-285.

\section{Copyrights}

Copyright for this article is retained by the author(s), with first publication rights granted to the journal.

This is an open-access article distributed under the terms and conditions of the Creative Commons Attribution license (http://creativecommons.org/licenses/by/4.0/). 